\section{Antibiotic Prophylaxis in Gastrointestinal System Endoscopy}

\section{Ali Riza Koksal*and Christina Ramazani-Necessary \\ Department of Gastroenterology and Hepatology, School of Medicine, Tulane University, 1430 Tulane Ave., SL-35 New Orleans, LA, USA}

\begin{abstract}
Infections are a rarely observed complication following gastrointestinal endoscopic procedures. All endoscopic procedures are not shown to be equally risky. Transient bacteremia after the routine diagnostic procedures and clinically significant de-novo infections after the interventional endoscopic procedures should be considered as different circumstances. In addition, patient-related factors also play a very important role in the decision of antibiotic prophylaxis. Although there are many guidelines on this controversial issue, the number of recently published studies is low and the information may need to be interpreted considering clinical experience. We aimed to present a general opinion about the principles of prophylactic antibiotic usage in gastrointestinal endoscopic procedures in light of the information coming from the main clinical guidelines and some recent studies.
\end{abstract}

\section{Abbreviation}

ESD: Endoscopic submucosal dissection; EMR: Endoscopic mucosal resection; NOTES: Endoscopic surgery through natural openings; POEM: Peroral endoscopic myotomy

\section{Introduction}

Antibiotic prophylaxis in gastrointestinal (GI) endoscopic procedures has been a controversial issue for many years. Which patients are in need? Which procedures require antibiotic prophylaxis? Which antibiotics should be used in which doses? Is it given before or after the procedure? There are many guidelines published by international

*Corresponding author: Ali Riza Koksal, Department of Gastroenterology and Hepatology, School of Medicine, Tulane University,1430 Tulane Ave., SL-35 New Orleans, LA, USA, Tel:+ 1 5044325694; E-mail: akoksal@tulane.edu

Citation: Koksal AR, Ramazani-Necessary C (2019) Antibiotic Prophylaxis in Gastrointestinal System Endoscopy. J Gastroenterol Hepatology Res 4: 025.

Received: October 28, 2019; Accepted: November 07, 2019; Published: December 09, 2019

Copyright: (C) 2019 Koksal AR and Ramazani-Necessary C. This is an openaccess article distributed under the terms of the Creative Commons Attribution License, which permits unrestricted use, distribution, and reproduction in any medium, provided the original author and source are credited. associations aiming to answer these questions [1,2]. Under normal conditions, occurrence of an infection after an endoscopic procedure is extremely rare. The main purpose of antibiotic prophylaxis is to prevent this rare complication. However, bacterial antibiotic resistance caused by unnecessary use of antibiotics, side effects of antibiotics, allergic reactions and drug costs are prohibitive factors in their use. Antibiotic prophylaxis was recommended for many gastrointestinal endoscopic procedures in previous years, especially in patients with heart valve disease, but this practice has completely changed today $[1,3]$.

After endoscopic procedures, infections occur in two ways; the first way is that a microorganism in the body transfers to the blood flow as a result of mucosal trauma, which is called 'bacterial translocation' or 'bacteremia'. Another way is through use of endoscope and/ or accessories to a previously known sterile cavity during procedures such as contrast injection, drainage, aspiration or pathological sampling [4].

In this regard, two important points should be considered when evaluating the patient:

1. Which procedure is going to be performed? Does the planned procedure pose a risk of a new infection or bacteremia?

2. What are the patient-dependent risk factors? What is the risk to the patient in terms of infectious complications? (Special patient groups such as patients with neutropenia, patients who have cirrhosis, renal failure or history of heart valve replacement).

\section{Bacteremia and Infection Risk of Gastrointestinal Endoscopic Procedures}

The risk of transient bacteremia following gastrointestinal endoscopic procedures is lower than that caused by many routine activities in daily life. For example, tooth brushing and flossing (20-68\%), using toothpicks (20-40\%), consuming chewable foods (7-51\%) have a risk of temporary bacteremia $[5,6]$.

\section{High-Risk GI Endoscopic Procedures for Bacteremia}

\section{Dilatation in esophageal strictures}

Multiple dilatations and malignancy-related dilatations have a higher risk [7].

\section{Sclerotherapy for esophageal varices}

The procedure of injecting a sclerosing agent into or around the varices is reported to have a $15 \%$ risk of bacteremia, but band ligation is not considered as a high risk [8]. In a recent study, 60 cirrhotic patients undergoing endoscopic band ligation for variceal bleeding and 112 elective ligation procedures were evaluated. Streptococcus mitis and Staphylococcus epidermidis were found in 3 post-procedural blood cultures. These findings were interpreted as transient bacteremia by the authors [9]. 


\section{Endoscopic retrograde cholangiopancreatography (ERCP)}

If there is a bile flow obstruction, the risk of bacteremia during the procedure as well as risk of post ERCP cholangitis are increased [10]. If biliary drainage is considered to be unsuccessful, antibiotics should be continued until drainage is achieved and cholangitis signs disappear. A review of the gastrointestinal endoscopic performance measures in ERCP and EUS procedures a published by European ESGE in 2018 emphasized the importance of pre-ERCP antibiotic use in patients with appropriate conditions [11].

\section{Procedures with High Risk for Infection Independent of Bacteremia}

\section{Fine needle aspiration biopsy during the endoscopic ultrasonography (EUS-FNA)}

Although this procedure has a low risk of bacteremia, the overall risk of infection has been found to be high [1]. The most important factor is the structure of the lesion. While the risk is higher with any intervention for cystic lesions, sampling of solid lesions is considered to be practically no risk of infection [12]. Prophylactic antibiotic usage before the puncture of cystic lesions is mentioned as another requirement for higher procedure performance in the ESGE review [11]. When all the results are evaluated, EUS-guided biliary drainage and cyst drainage are considered as high risk for infection and bacteremia [1].

\section{Percutaneous endoscopic feeding tube placement (Gastrostomy-PEG- or Jejunostomy-PEJ-)}

Studies have shown that pre-procedure antibiotic administration reduces the risk of wound infection at the site of tube insertion [13]. In a recent retrospective study of 781 patients, the rate of peristomal infection was reported to be $21.9 \%$. The risk of peristomal infection was higher in patients receiving chemotherapy or radiotherapy [14].

The efficacy of submucosal gentamicin lavage before myotomy was evaluated in 124 POEM cases. This treatment does not reduce the risk of infection but may reduce the systemic inflammatory response [15]. In a prospective randomized controlled study by Lee et al., 100 patients undergoing colorectal ESD were evaluated. Post-ESD electrocoagulation syndrome was significantly low in the prophylactic ampicillin sulbactam group. In addition, C-reactive protein (CRP) elevation and abdominal pain were also observed less frequently in this group [16]. Although there is not much new information about these procedures in the literature, these procedures can be considered as high-risk procedures for bacteremia and de novo infections.

\section{Procedures with Low Risk for Infection and Bacteremia}

Diagnostic gastroscopy, colonoscopy and flexible rectosigmoidoscopy are considered low risk for infection and bacteremia [4,17]. Although a recent case of Streptococcus Bovis endocarditis has been reported after colonoscopic polypectomy, authors concluded that performing biopsy and polypectomy during the procedure is considered low-risk for infection and bacteremia [18].

\section{Patient Factors and Special Patient Groups}

\section{Cardiac diseases}

Patients who have prosthetic heart valves or history of infective endocarditis are considered to be high-risk cardiac lesions. However, guidelines in both cardiology and gastroenterology do not recommend prophylaxis before the GI endoscopic procedures even in these patients $[1,2]$. The only exception to this is to give prophylaxis in this group of patients if there is any known GI infection associated with active Enterococci before the procedure.

\section{Immunocompromised patients}

Although there are not enough studies with a high level of evidence, the risk of infection after GI endoscopy is increased in patients with severe neutropenia $\left(<500\right.$ cells $\left./ \mathrm{mm}^{3}\right)$ or advanced hematologic malignancy [19]. Therefore, to give an antibiotic prophylaxis before high-risk procedures is recommended. These patients should be followed up closely after low-risk procedures even if antibiotics are not given. Antibiotic prophylaxis before the endoscopic procedure is not recommended for immunocompromised patients who do not meet these conditions [1].

\section{Cirrhosis}

Patients with cirrhosis who present with GI bleeding should be given antibiotics whether endoscopic procedure is planned or not [20]. In addition, since the risk of bacterial translocation is higher in patients with cirrhosis and ascites, prophylaxis before high-risk procedures may be appropriate [21].

\section{Patients with synthetic vascular graft}

Prophylaxis is not required for low-risk endoscopic procedures. In high-risk endoscopic procedures, if the endoscopic procedure is elective, it is recommended to wait for 6 months after graft placement. If the patient is unable to wait for that period of time, the antibiotic prophylaxis should be given [2].

\section{Patients with joint prosthesis}

Antibiotic prophylaxis prior to GI endoscopic procedures is not recommended in the main guidelines $[1,22]$.

\section{Patients with peritoneal dialysis}

Cases of peritonitis have been reported after colonoscopy and especially after polypectomy. In a study retrospectively evaluated 45 peritoneal dialysis patients undergoing endoscopy. The authors found that oral or intravenous prophylactic antibiotic use prior to nonEGD (non-esophagogastroduodenoscopy) examination significantly reduced the endoscopy associated peritonitis rate compared to that without antibiotic use [23]. However, in a recent prospective study showed that there was no significant difference in the rate of peritonitis between pre-procedure intraperitoneal antibiotic (ceftazidime) and non-antibiotic groups. In the same study, it was shown that polypectomy did not change the frequency of peritonitis [24]. Furthermore, The American Society of Gastrointestinal Endoscopy (ASGE) recommends that the peritoneal cavity should be empty and give antibiotic prophylaxis before the colonoscopy [1].

\section{Which antibiotic should be given in which dose?}

Antibiotics and their dosages according to patient and procedure risk are summarized in the table $1[1,25,26]$. 


\begin{tabular}{|c|c|c|}
\hline Procedure & Patient/Clinical condition & Antibiotics and doses \\
\hline PEG/PEJ & All Patients & $\begin{array}{l}\text { - Cefazolin } \\
\text { o } \quad 2 \mathrm{gr} \text { IV }<120 \mathrm{~kg} \text {. within } 60 \mathrm{~min} \text { before the procedure } \\
\text { o } 3 \mathrm{gr} \mathrm{IV} \geq 120 \mathrm{~kg} \text {. } \\
\text { Penicillin allergy present: } \\
\text { o Clindamycin } 900 \mathrm{mg} \mathrm{IV} \\
\text { MRSA risk present: } \\
\text { o Vancomycin } 15 \mathrm{mg} / \mathrm{kg}(\max 2 \mathrm{~g}) \mathrm{IV} \text { infused over } 60 \\
\text { to } 90 \text { min and beginning within } 120 \text { min before the } \\
\text { procedure }\end{array}$ \\
\hline ERCP & $\begin{array}{l}\text { Biliary obstruction and cholangitis } \\
\text { If bile duct drainage is insufficient (Primer sclerosing cholangitis, hilar } \\
\text { stenosis, biliary problems after liver transplantation) } \\
\text { If drainage is sufficient, antibiotics are not required. }\end{array}$ & $\begin{array}{l}\text { - Ciprofloxacin } 500 \mathrm{mg} \text { oral within } 60 \mathrm{~min} \text { before the proce- } \\
\text { dure or the other alternatives, } \\
\text { - Ciprofloxacin } 400 \mathrm{mg} \text { IV infused over } 60 \mathrm{~min} \text { and begin- } \\
\text { ning within } 120 \mathrm{~min} \text { before the procedure } \\
\text { - Amoxicillin-clavulanate } 1750 \mathrm{gr} \text { oral } \\
\text { - Ampicillin-sulbactam } 3 \mathrm{gr} \text {. IV } \\
\text { - Ampicillin } 2 \mathrm{gr}+\text { gentamicin } 5 \mathrm{mg} / \mathrm{kg} \\
\text { IV Antibiotics should be continue until to provide effective } \\
\text { biliary drainage }\end{array}$ \\
\hline EUS FNA & $\begin{array}{l}\text { Drainage of pancreatic or mediastinal cysts } \\
\text { Sampling for cystic mass lesions } \\
\text { Walled-off pancreatic necrosis }\end{array}$ & $\begin{array}{l}\text { - Ciprofloxacin } 500 \mathrm{mg} \text { oral within } 60 \mathrm{~min} \text { before the pro- } \\
\text { cedure or, } \\
\text { - Ciprofloxacin } 400 \mathrm{mg} \text { IV infused over } 60 \mathrm{~min} \text { and begin- } \\
\text { ning within } 120 \mathrm{~min} \text { before the procedure } \\
\text { - Continue } 3 \text { days post-procedure. }\end{array}$ \\
\hline ESD EMR POEM & $\begin{array}{l}\text { Although there is no sufficient data, it can be given according to clinical } \\
\text { experience. }\end{array}$ & Same as options for EUS FNA \\
\hline $\begin{array}{l}\text { High risk endoscopic procedures for bacte- } \\
\text { remia } \\
\text { (Dilatation of esophageal strictures, sclero- } \\
\text { therapy to esophageal varices) }\end{array}$ & $\begin{array}{l}\text { Immunocompromised patients } \\
\text { - Severe neutropenia }\left(<500 \mathrm{cell} / \mathrm{mm}^{3}\right) \\
\text { - Advanced hematologic malignancy } \\
\text { Cirrhosis with ascites }\end{array}$ & $\begin{array}{l}\text { - Amoxicillin } 2 \mathrm{gr} \text { oral within } 60 \mathrm{~min} \text { before the procedure } \\
\text { or, } \\
\text { - Ampicillin } 2 \mathrm{gr} \mathrm{IV} / \mathrm{IM} \text { within } 60 \mathrm{~min} \text { before the procedure } \\
\text { - Penicillin allergy present: } \\
\text { - Clindamycin } 900 \mathrm{mg} \mathrm{IV}\end{array}$ \\
\hline Colonoscopy or Polypectomy & Patients with Peritoneal dialysis & $\begin{array}{l}\text { Ampicillin } 2 \mathrm{gr}+\text { gentamicin } 5 \mathrm{mg} / \mathrm{kg} \text { IV Max: } 120 \mathrm{mg} \text { pre-pro- } \\
\text { cedure }\end{array}$ \\
\hline
\end{tabular}

Table 1: Antibiotic doses according to endoscopic procedures and clinical conditions.

EUS: Endoscopic Ultrasonography; FNA: Fine Needle aspiration; ERCP: Endoscopic retrograde Cholangiopacreatography; EMR: Endoscopic mucosal resection; ESD: Endoscopic submucosal dissection; MRSA: Meticillin Resistant Staphylococcus aureus; POEM: Peroral endoscopic myotomy

\section{Conclusion}

Antibiotic prophylaxis in gastrointestinal endoscopic procedures is strongly recommended in two conditions: before the gastrointestinal endoscopic procedures with a high risk of developing new infections or patients whose disease increase susceptibility to infection and who will undergo a high bacteremia risk procedure. These guidelines form a road map based on the information provided by the medical literature. However, in borderline topics like antibiotic prophylaxis, it is necessary to interpret these information within one's own clinical experience.

\section{Conflict of Interest}

None declared.

\section{Source of Funding}

Ali Riza Koksal was supported by funds received from the Akdamar Fellowship Program, Department of Gastroenterology and Hepatology, Tulane University Health Sciences Center.

\section{References}

1. Khashab MA, Chithadi KV, Acosta RD, Bruining DH, Chandrasekhara $\mathrm{V}$, et al. (2015) Antibiotic prophylaxis for GI endoscopy. GastrointestEndosc 81: 81-89.
2. Wilson W, Taubert KA, Gewitz M, Lockhart PB, Baddour LM, et al. (2007) Prevention of infective endocarditis: guidelines from the American Heart Association: a guideline from the American Heart Association Rheumatic Fever, Endocarditis, and Kawasaki Disease Committee, Council on Cardiovascular Disease in the Young, and the Council on Clinical Cardiology, Council on Cardiovascular Surgery and Anesthesia, and the Quality of Care and Outcomes Research Interdisciplinary Working Group. Circulation 116: 1736-1754.

3. Rey JR, Axon A,Budzynska A, Kruse A, Nowak A (1998) Guidelines of the European Society of Gastrointestinal Endoscopy (E.S.G.E.) antibiotic prophylaxis for gastrointestinal endoscopy. European Society of Gastrointestinal Endoscopy. Endoscopy 30: 318-324.

4. Norfleet RG, Mitchell PD, Mulholland DD, Philo J (1981) Does bacteremia follow upper gastrointestinal endoscopy? Am J Gastroenterol 76: $420-422$.

5. Forner L, Larsen T, Kilian M, Holmstrup P (2006)Incidence of bacteremia after chewing, tooth brushing and scaling in individuals with periodontal inflammation. J Clin Periodontol 33: 401-407.

6. Sconyers JR, Crawford JJ, Moriarty JD (1973) Relationship of bacteremia to toothbrushing in patients with periodontitis. J Am Dent Assoc 87: 616-622.

7. Nelson DB, Sanderson SJ, Azar MM (1998) Bacteremia with esophageal dilation. GastrointestEndosc 48: 563-567. 
8. Snady H, Korsten MA, Waye JD (1985) The relationship of bacteremia to the length of injection needle in endoscopic varicealsclerotherapy. GastrointestEndosc 31:243-246.

9. Maimone S, Saffioti F, Filomia R, Caccamo G, Saitta C, et al. (2018) Elective endoscopic variceal ligation is not a risk factor for bacterial infection in patients with liver cirrhosis. Dig Liver Dis 50: 366-369.

10. Cotton PB, Connor P, Rawls E, Romagnuolo J (2008) Infection after ERCP, and antibiotic prophylaxis: a sequential quality-improvement approach over 11 years. Gastrointest Endosc 67: 471-475.

11. Domagk D, Oppong KW, Aabakken L, Czako L, Gyokeres T, et al. (2018) Performance measures for endoscopic retrograde cholangiopancreatography and endoscopic ultrasound: A European Society of Gastrointestinal Endoscopy (ESGE) Quality Improvement Initiative. United European Gastroenterol J 6: 1448-1460.

12. Guarner-Argente C, Shah P, Buchner A, Ahmad NA, Kochman ML, Ginsberg GG (2011) Use of antimicrobials for EUS-guided FNA of pancreatic cysts: a retrospective, comparative analysis. GastrointestEndosc 74:81-86.

13. Lipp A, Lusardi G (2013) Systemic antimicrobial prophylaxis for percutaneous endoscopic gastrostomy. Cochrane Database Syst Rey Cd005571.

14. Vizhi K, Rao HB, Venu RP (2018) Percutaneous endoscopic gastrostomy site infections-Incidence and risk factors. Indian J Gastroenterol 37: 103-107.

15. Bayer J, Vackova Z, Svecova H, StirandP, Spicak J, et al. (2018) Gentamicin submucosal lavage during peroral endoscopic myotomy (POEM): a retrospective analysis. Surg Endosc 32: 300-306.

16. Lee SP, Sung IK, Kim JH, Lee SY, Park HS, et al. (2017) A randomized controlled trial of prophylactic antibiotics in the prevention of electrocoagulation syndrome after colorectal endoscopic submucosal dissection. GastrointestEndosc 86:349-357.

17. Goldman GD, Miller SA, Furman DS, Brock D, Ryan JL, McCallum RW (1985) Does bacteremia occur during flexible sigmoidoscopy? Am J Gastroenterol 80: 621-623.
18. Chongprasertpon N, Cusack R, Coughlan JJ, Chung WT, Leung CH, et al. (2019) Streptococcus bovis Endocarditis after Colonic Polypectomy. Eur J Case Rep Intern Med 6: 001110

19. Bianco JA, Pepe MS, Higano C, Applebaum FR, McDonald GB, et al (1990) Prevalence of clinically relevant bacteremia after upper gastrointestinal endoscopy in bone marrow transplant recipients. Am J Med 89: $134-136$.

20. Chavez-Tapia NC, Barrientos-Gutierrez T, Tellez-Avila F, Soares-Weiser K, Mendez-Sanchez N, et al. (2011) Meta-analysis: antibiotic prophylaxis for cirrhotic patients with upper gastrointestinal bleeding - an updated Cochrane review. Aliment Pharmacol Ther 34: 509-518.

21. Fernandez J, Ruiz del Arbol L, Gomez C, Durandez R, Serradilla R, et al. (2006) Norfloxacinvs ceftriaxone in the prophylaxis of infections in patients with advanced cirrhosis and hemorrhage. Gastroenterology 131: $1049-1056$.

22. Oliver G, Lowry A, Vernava A, Hicks T, Burnstein M, et al. (2000) Practice parameters for antibiotic prophylaxis--supporting documentation The Standards Task Force. The American Society of Colon and Rectal Surgeons. Dis Colon Rectum 43: 1194-1200.

23. Wu HH, Li IJ, Weng CH, Lee CC, Chen YC, et al. (2013) Prophylactic antibiotics for endoscopy-associated peritonitis in peritoneal dialysis patients. PLoS One 8: e71532.

24. Al-Hwiesh AK, Abdul-Rahman IS, Hussameldeen MA, Al-Audah N, Abdelrahman A, et al. (2017) Colonoscopy in automated peritoneal dialysis patients: value of prophylactic antibiotics: a prospective study on a single antibiotic. Int J Artif Organs 40: 550-557.

25. Bratzler DW, Dellinger EP, Olsen KM, Perl TM, Auwaerter PG, et al (2013) Clinical practice guidelines for antimicrobial prophylaxis in surgery. Am J Health Syst Pharm 70: 195-283.

26. Piraino B, Bailie GR, Bernardini J, Boeschoten E, Gupta A, et al. (2005) Peritoneal dialysis-related infections recommendations: 2005 update. Perit Dial Int 25: 107-131. 


\section{Hit}

Journal of Anesthesia \& Clinical Care

Journal of Addiction \& Addictive Disorders

Advances in Microbiology Research

Advances in Industrial Biotechnology

Journal of Agronomy \& Agricultural Science

Journal of AIDS Clinical Research \& STDs

Journal of Alcoholism, Drug Abuse \& Substance Dependence

Journal of Allergy Disorders \& Therapy

Journal of Alternative, Complementary \& Integrative Medicine

Journal of Alzheimer's \& Neurodegenerative Diseases

Journal of Angiology \& Vascular Surgery

Journal of Animal Research \& Veterinary Science

Archives of Zoological Studies

Archives of Urology

Journal of Atmospheric \& Earth-Sciences

Journal of Aquaculture \& Fisheries

Journal of Biotech Research \& Biochemistry

Journal of Brain \& Neuroscience Research

Journal of Cancer Biology \& Treatment

Journal of Cardiology: Study \& Research

Journal of Cell Biology \& Cell Metabolism

Journal of Clinical Dermatology \& Therapy

Journal of Clinical Immunology \& Immunotherapy

Journal of Clinical Studies \& Medical Case Reports

Journal of Community Medicine \& Public Health Care

Current Trends: Medical \& Biological Engineering

Journal of Cytology \& Tissue Biology

Journal of Dentistry: Oral Health \& Cosmesis

Journal of Diabetes \& Metabolic Disorders

Journal of Dairy Research \& Technology

Journal of Emergency Medicine Trauma \& Surgical Care

Journal of Environmental Science: Current Research

Journal of Food Science \& Nutrition

Journal of Forensic, Legal \& Investigative Sciences

Journal of Gastroenterology \& Hepatology Research

Journal of Gerontology \& Geriatric Medicine
Journal of Genetics \& Genomic Sciences

Journal of Hematology, Blood Transfusion \& Disorders

Journal of Human Endocrinology

Journal of Hospice \& Palliative Medical Care

Journal of Internal Medicine \& Primary Healthcare

Journal of Infectious \& Non Infectious Diseases

Journal of Light \& Laser: Current Trends

Journal of Modern Chemical Sciences

Journal of Medicine: Study \& Research

Journal of Nanotechnology: Nanomedicine \& Nanobiotechnology

Journal of Neonatology \& Clinical Pediatrics

Journal of Nephrology \& Renal Therapy

Journal of Non Invasive Vascular Investigation

Journal of Nuclear Medicine, Radiology \& Radiation Therapy

Journal of Obesity \& Weight Loss

Journal of Orthopedic Research \& Physiotherapy

Journal of Otolaryngology, Head \& Neck Surgery

Journal of Protein Research \& Bioinformatics

Journal of Pathology Clinical \& Medical Research

Journal of Pharmacology, Pharmaceutics \& Pharmacovigilance

Journal of Physical Medicine, Rehabilitation \& Disabilities

Journal of Plant Science: Current Research

Journal of Psychiatry, Depression \& Anxiety

Journal of Pulmonary Medicine \& Respiratory Research

Journal of Practical \& Professional Nursing

Journal of Reproductive Medicine, Gynaecology \& Obstetrics

Journal of Stem Cells Research, Development \& Therapy

Journal of Surgery: Current Trends \& Innovations

Journal of Toxicology: Current Research

Journal of Translational Science and Research

Trends in Anatomy \& Physiology

Journal of Vaccines Research \& Vaccination

Journal of Virology \& Antivirals

Archives of Surgery and Surgical Education

Sports Medicine and Injury Care Journal

International Journal of Case Reports and Therapeutic Studies

Submit Your Manuscript: http://www.heraldopenaccess.us/Online-Submission.php 